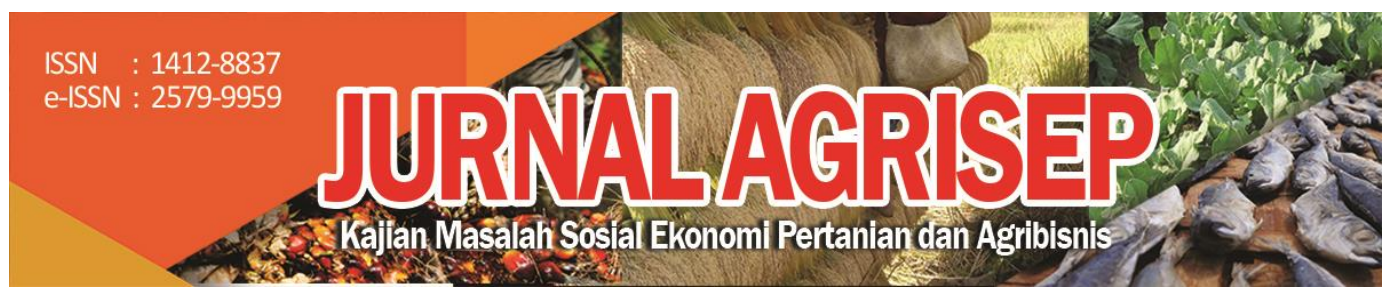

DOI: $10.31186 /$ jagrisep.20.1.103-116

\title{
ANALISIS KEPUASAN PETANI SAYURAN ORGANIK ANGGOTA GAPOKTAN BANGKIT MERBABU DALAM MENGIKUTI PROGRAM KEMITRAAN USAHA DENGAN PT BLOOM AGRO
}

\author{
Analysis of Satisfaction of Organic Vegetable Farmers of Bangkit \\ Merbabu Farmer Group Association in Following Business Partnership \\ Program with PT Bloom Agro

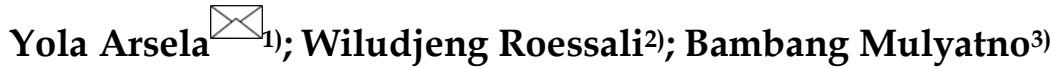 \\ 1)23) Jurusan Agribisnis Fakultas Peternakan dan Pertanian Universitas \\ Diponegoro Semarang \\ Email: yola.arsela@gmail.com
}

\begin{abstract}
A partnership is an effort to involve various components to work together toward a common goal. This study aims to analyze the implementation of the partnership between farmers and PT Bloom Agro and to analyze the level of farmers' satisfaction with the company. This study was conducted in January-February 2020 at the Bangkit Merbabu Farmer Group Association, Getasan Subdistrict, Semarang Regency. This study used a case study method with a sample size of 50 respondents who were determined by purposive sampling. Furthermore, the data were analyzed using Importance Performance Analysis (IPA) and Customer Satisfaction Index (CSI). The study found ten attributes that are used as an assessment in implementing a partnership between farmers and PT Bloom Agro. The calculation from the Importance Performance Analysis (IPA) found one attribute that became the main priority (Quadrant I), namely the field technicians' level of knowledge. The four attributes that need to be maintained (Quadrant II) are clear standard operating procedures regarding product quality determination, selling price suitability, ease of product delivery, and increased revenue. The four low priority attributes (Quadrant III) are seed quality, field technicians response to farmer complaints, the suitability of products absorbed by the company, and the timing of payment. One redundant attribute (Quadrant IV) is the technology provided. The results of the Customer Satisfaction Index (CSI) of 0.88 or $88 \%$ indicate that the performance of PT Bloom Agro has made farmers very satisfied.
\end{abstract}


Keywords : farmer's satisfaction, organic vegetables, partnership, PT Bloom Agro

\begin{abstract}
ABSTRAK
Kemitraan adalah partisipasi pihak atau berbagai komponen yang bekerja bersama untuk menggapai hasil akhir bersama. Penelitian ini bertujuan untuk menganalisis implementasi kemitraan dan taraf kepuasan petani dengan kinerja dari PT Bloom Agro. Penelitian dilakukan pada bulan Januari sampai Februari 2020 di Gapoktan Bangkit Merbabu yang berlokasi di Kecamatan Getasan. Metode penelitian adalah studi kasus dengan sampel yang di identifikasi melalui purposive sampling dan berjumlah 50 responden. Performance Importance Anlysis (IPA) dan Customer Satisfaction Index (CSI) digunakan untuk memvalidasi analisis data. Hasil dari penelitian menunjukan bahwa 10 atribut digunakan sebagai skor untuk menilai pelaksanaan kinerja antara petani dengan PT Bloom Agro. Hasil akhir perhitungan Performance Importance Analysis (IPA) memiliki 1 atribut yang terletak di prioritas utama yaitu taraf pengetahuan teknisi lapangan. Pada Kuadran II (pemeliharaan) adalah standar operasional prosedur (SOP), kemudahan pengiriman produk, harga jual yang sesuai dan penghasilan yang meningkat. Kuadran III (prioritas rendah) yaitu kualitas benih yang dihasilkan, tanggapan teknisi lapangan terhadap masalah petani, tingkat hasil produksi yang diserap oleh perusahaan dan tenggang masa pembayaran. Kuadran IV (berlebihan) terdapat teknologi yang difasilitasi perusahaan. Customer Satisfaction Index atau CSI hasil perhitungan yang didapat yaitu 0,88 atau $88 \%$ yang menyatakan bahwa kinerja dari PT Bloom Agro diterima dengan sangat baik (merasa sangat puas) oleh petani mitra.
\end{abstract}

Kata kunci : kemitraan, kepuasaan petani, PT Bloom Agro, sayuran organik

\title{
PENDAHULUAN
}

Sektor pertanian (agraris) menjadi sektor utama sebagai mata pencaharian penduduk Indonesia khususnya di pedesaan. Holtikultura (sayuran) menjadi salah satu sub sektor pertanian pedesaan yang dikembangkan dengan sistem pertanian organik dan non organik. Penerapan sistem pertanian organik belum sepenuhnya mendominasi pertanian di Indonesia namun dengan demikian sudah berkembang secara baik, dimana masyarakat sadar akan pentingnya sayuran organik terhadap kesehatan (Yurlisa dan Susanti, 2018). Kesadaran masyarakat tersebut memicu permintaan sayuran organik dan pertambahan luas lahan yang semakin meningkat. Peningkatan total luas lahan pertanian organik berkisar 39,4\% dari mulai tahun 2016 ke tahun selanjutnya yaitu 2017 dan di tahun 2017 ke 2018 sekitar 17,3\%, total luas lahan pertanian organic di tahun 2018 sebanyak 251.630,98 ha (SPOI, 2019).

Holtikultura Sayuran jenis organik dapat meningkatkan kesehatan karena mengandung gizi yang lebih banyak dan terhindar dari residu kimia yang membahayakan bagi tubuh manusia (Sanusi, 2010). Jaminan mutu keaslian

104 | Yola Arsela; Wiludjeng Roessali; Bambang Mulyatno Setiawan; Analisis... 
organik pada suatu bahan pangan terletak pada persyaratan produksi yang sesuai, pelabelan organik dan adanya suatu ketentuan produk organik yang telah disepakati bersama. Jaminan tersebut ada pada Standar Nasional Indonesia mengenai penetapan pertanian organik di Indonesia dari hulu sampai hilir. Sertifikasi merupakan prosedur dari lembaga pemerintah yang memberikan jaminan tertulis mengenai keaslian atau syarat dari suatu bahan pangan telah dilakukan dengan baik dan sesuai (Yurlisa dan Susanti, 2018). Sayuran organik akan semakin percaya dikonsumsi konsumen apabila sayuran organik telah tersertifikasi dengan baik. Kualitas produk organik harus dapat memberikan dampak positif bagi konsumen selain itu juga mampu bersaing di pasar daerah lokal maupun luar negeri dalam memenuhi kebutuhan konsumen.

Sentra utama penghasil sayuran terbesar ketiga di Indonesia yaitu Jawa Tengah. Daerah penghasil sayuran organik salah satunya yaitu di Kecamatan Getasan Kabupaten Semarang terdapat Gabungan Kelompok Tani Bangkit Merbabu yang telah membudidayakan sayuran organik secara aktif. Kecamatan Getasan memiliki lahan pertanian (ladang) yang membudidayakan tanaman holtikultura sebesar 4.021,74 ha (BPS, 2017). Anggota Gapoktan Bangkit Merbabu dalam membudidayakan sayuran organiknya terdapat beberapa masalah yang muncul yaitu persedian sayuran melimpah akan tetapi permintaan rendah dan ketidakpastian harga, sehingga petani mengalami kerugian tenaga, waktu dan materi. Solusi yang dapat membantu dalam mengatasi permasalahan tersebut yaitu adanya kerjasama (kemitraan) antara petani dan perusahaan.

PT Bloom Agro (perusahaan dibidang eksportir) menawarkan program kemitraan kepada petani anggota Gapoktan Bangkit Merbabu untuk membantu mengatasi masalah yang dihadapi oleh para petani. Menurut Raharjo (2018) tujuan kemitraan (kedua belah pihak) yaitu dapat meningkatkan sumber daya kelompok mitra dari segi kualitas dan kuantitas, kenaikan taraf hidup dan meningkatkan usaha mandiri yang berkelanjutan. Namun selain dari itu, pada saat menjalani kemitraan juga terdapat beberapa kendala di dalamnya yang berperngaruh terhadap kemitraan yang terjalin. Respon petani menurun dalam hal kerjasama, kurangnya komitmen kedua belah pihak dan keterlambatan menyetor dan membayar produk merupakan ciri dari kendala dalam kemitraan. Menurut Oglamando et al. (2017) hambatan dari kemitraan diantaranya kemampuan negosiasi yang rendah dan ketidaksiplinan kedua belah pihak dalam menjalaninya.

Aktualisasi kemitraan bisa menguntungkan bagi petani terutama dari segi finansial yaitu harga produk yang lebih tinggi dan terjamin sehingga petani akan merasa puas dalam bermitra. Petani mitra merasa puas merupakan hal yang penting untuk mendukung keselarasan kerjasama kedua belah pihak yaitu bagi petani dan perusahaan. Maka dari itu, peneliti menelaah topik ini agar dapat mengetahui keutamaan servis yang telah diberikan oleh PT Bloom Agro kepada 
petani anggota Gapoktan Bangkit Merbabu. Tujuan dari penelitian ini yaitu : (1). Untuk menganalisis implementasi kemitraan yang terikat antara petani anggota Gapoktan Bangkit Merbabu dengan PT Bloom Agro (2). Untuk mengetahui tingkat kepuasan petani anggota Gapoktan Bangkit Merbabu selama mengikuti program kemitraan usaha dengan PT Bloom Agro.

\section{METODE PENELITIAN}

Studi kasus merupakan metode yang digunakan pada penelitian ini. Studi kasus merupakan kegiatan ilmiah yang dilakukan secara mendalam dan terperinci terkait suatu kejadian untuk memperoleh pengetahuan yang mendalam mengenai suatu kejadian atau peristiwa (Hidayatulloh et al., 2015). Penelitian ini dilakukan di Kecamatan Getasan Kabupaten Semarang pada Januari 2020 - Februari 2020. Penentuan lokasi dilakukan dengan pertimbangan bahwa banyak petani di Kecamatan Getasan yang membudidayakan sayuran organik dan menjalin kerjasama kemitraan dengan PT Bloom Agro. Langkah selanjutnya memilih kelompok tani yang akan diteliti yaitu Gapoktan Bangkit Merbabu dengan didasarkan bahwa anggotanya banyak bermitra dengan PT Bloom Agro. Purposive sampling merupakan metode yang digunakan untuk penentuan sampel dari populasi yang ditentukan secara sengaja dengan persyaratan tertentu (Mufarriqoh, 2020). Metode penentuan sampel menggunakan purposive sampling, dimana jumlah sampel yang dipilih sebanyak 50 orang petani dan memiliki pertimbangan khusus yaitu telah membudidayakan sayuran organik minimal 3 tahun lamanya dari pertanian konvensional (tersertifikasi organik) dan bermitra dengan PT Bloom Agro dengan menyetor sayuran organik secara kontinu ke PT Bloom Agro.

\section{Metode Analisis data}

\section{Importance Performance Analysis (IPA)}

Sari (2018) menyebutkan bahwa Importance Performance Analysis (IPA) yaitu suatu alat ukur yang digunakan untuk mengetahui dan mememahami kesenjangan yang terjadi atas kinerja dari suatu variabel dan harapan responden berdasarkan variable tersebut. Penetapan atribut dilakukan dengan cara mewawancarai keynote person kemudian menetapkan atribut apa saja yang layak menjadi tolak ukur dalam penilaian pelaksanaan kemitraan. Pengukuran tingkat kepentingan (harapan) menggunakan skala likert yaiitu 5 tingkat dimana ada sangat penting $=5$, penting $=4$, netral $=3$, tidak penting $=2$ dan sangat tidak penting $=1$. Berikut adalah tahapan-tahapan untuk mengukur Importance Performance Analysis (IPA) (Iswari et al., 2015): Pertama, menghitung tingkat kesesuain (Tki) antara tingkat kinerja yaitu $\mathrm{Xi}$ dan tingkat kepentingan yaitu Yi dengan rumus berikut:

106 | Yola Arsela; Wiludjeng Roessali; Bambang Mulyatno Setiawan; Analisis... 


$$
T k i=\frac{X i}{Y i} \times 100 \%
$$

dimana Tki adalah tingkat kesesuaian responden, $Y_{i}$ adalah skor penilaian kepentingan dan $X_{i}$ adalah skor penilaian kinerja.

Kedua, setiap atribut yang diimpresi oleh konsumen kemudian dihitung rata-ratanya, dengan rumus :

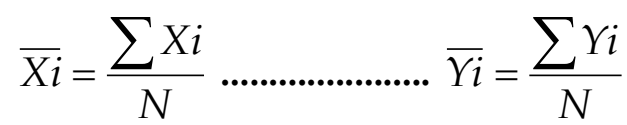

dimana $\overline{X i}$ adalah bobot rata-rata penilaian kinerja atribut ke-i, $\overline{Y i}$ adalah bobot rata-rata penilaian kepentingan atribut ke-i dan $\mathrm{N}$ adalah jumlah responden.

Ketiga, seluruh atribut tingkat kepentingan $(\mathrm{Y})$ dan kinerja $(\mathrm{X})$ yang menjadi batas dalam diagram kartesius dihitung rata-ratanya dengan rumus :

$$
\overline{\overline{X i}}=\frac{\sum_{i-1}^{n} \overline{X i}}{n} \ldots \ldots \ldots \ldots \ldots \ldots . . . . . \overline{\overline{Y i}}=\frac{\sum_{i-1}^{n} \overline{Y i}}{n}
$$

dimana $\overline{\overline{X i}}$ adalah rata-rata skor tingkat kinerja responden dari seluruh atribut, $\overline{\overline{Y i}}$ adalah rata-rata tingkat kepentingan dari seluruh atribut dan $\mathrm{n}=$ jumlah atribut.

Nilai $\overline{\overline{X i}}$ dan $\overline{\overline{Y i}}$ ditujukan untuk pasangan kordinat titik atribut yang menjelaskan letak suatu posisi atribut dalam diagram kartesius. Penjabaran nilai tiap atribut dalam diagram kartesius bisa dilihat dibawah ini :

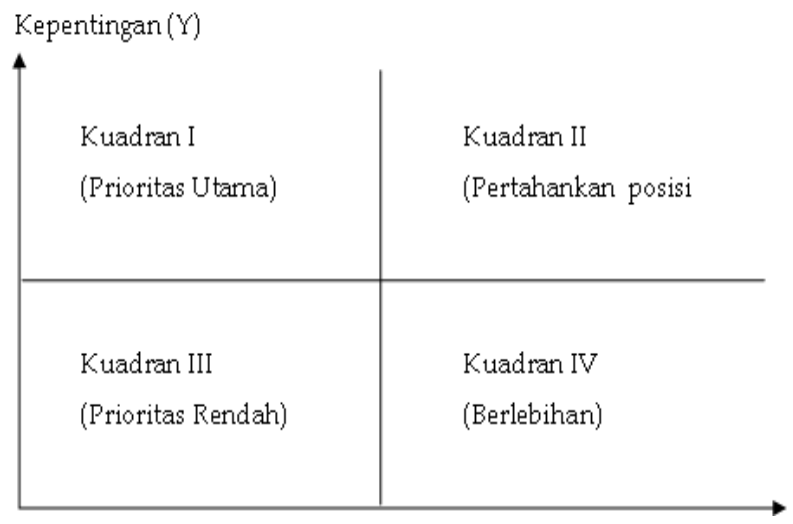

Gambar 1.

Diagram Kartesius (Bambang, 2013) 
Prioritas utama (Kuadran I) yaitu daerah yang memiliki tingkat kepuasaan sangat rendah. Pada kuadran ini produk atau jasa dianggap sangat penting oleh petani, akan tetapi jauh dari kata sesuai dengan harapan sehingga perlu dilakukan perbaikan yang menjadi prioritas utamanya.

Pertahankan prestasi (Kuadran II) yaitu atribut produk atau jasa yang diharapkan oleh petani telah sesuai dengan yang dirasakan oleh petani, sehingga tingkat kepuasaan lebih meningkat

Prioritas rendah (Kuadran III), dimana suatu atribut dianggap kurang penting oleh petani dan tidak terlalu spesial kinerja yang diberikan. Atribut ini tidak berpengaruh terlalu penting sehingga perlu dipertimbangkan kembali dan diperhatikan guna peningkatan kualitas jasanya.

Berlebihan (Kuadran IV), dimana pada kuadran ini atribut dirasa tingkat kepentingannya dianggap kurang penting atau rendah oleh petani, akan tetapi kinerja yang dimiliki tinggi.

\section{Costumer Satisfaction Index (CSI)}

Menurut Rangkuti (2006), langkah-langkah menganalisis Indeks Kepuasan Pelanggan atau CSI yaitu : (1) Nilai rata-rata tingkat kepentingan diubah menjadi angka presentase dari total rata-rata tingkat kepentingan seluruh atribut (menghitung Weighting Factor), (2) Tingkat kinerja dari masingmasing atribut dikali dengan WF masing-masing atribut (Weight Score), (3) Weight Score (WS) dari semua atribut dijumlahkan untuk mengetahui Weight Total (4) Menghitung nilai CSI yaitu dengan WT dibagi dengan 5 (skala maksimum yang digunakan). Menurut Arifin (2015) kriteria kepuasan dalam skala likert dibagi menjadi 5 yaitu $0 \%-20 \%, 21 \%-40 \%, 41 \%-60 \%, 61 \%-80 \%$ dan $81 \%-100 \%$ dengan penjelasan sebagai berikut : tidak puas, kurang puas, cukup puas, puas dan sangat puas.

\section{HASIL DAN PEMBAHASAN}

\section{Gambaran Umum Perusahaan}

PT Bloom Agro adalah perusahaan dari Indonesia yang bergerak dibidang sosial dan pertanian. Perusahaan ini berdiri pada Tahun 2009 oleh Emily Sutanto yang bertujuan untuk mempromosikan pertanian berkelanjutan dan meningkatkan rasa kemanusiaan (Sunria, 2020). Perusahaan ini berpusat di Jakarta dan mempunyai petani mitra di beberapa daerah yang memproduksi beras dan sayuran organik. Salah satu cabang mitranya yaitu petani sayuran organik di anggota Gapoktan Bangkit Merbabu yang ada di Kecamatan Getasan Kabupaten Semarang. Kerjasama perusahaan dengan petani mitra berlangsung sejak tahun 2016.

108 | Yola Arsela; Wiludjeng Roessali; Bambang Mulyatno Setiawan; Analisis... 
Hasil produksi sayuran organik dari petani dan telah di packing akan disetor ke PT Bloom Agro kemudian akan di ekspor ke Singapura untuk memenuhi permintaaan konsumen. PT Bloom Agro bekerjasama dengan The Frankfood Company untuk memasarkan sayuran organik ke tangan konsumen yang ada di Singapura. Pengirimannya dengan sistem delivery yang dilakukan sampai ke pintu rumah konsumen yang ada di Singapura (Sunria, 2020).

\section{Karakteristik Responden}

Karaktersitik responden yang dicermati pada penelitian ini mencakup usia responden, tingkat pendidikan dan luas lahan responden. Pada Tabel 1. diketahui bahwa dari segi usia responden terletak pada rentang umur 21-80 tahun. Responden sebanyak 47 orang berada pada rentang umur 21-65, kondisi tersebut menunjukan bahwa responden berada pada usia produktif, dimana responden masih memiliki kemampuan fisik untuk mengelola usahataninya. Menurut Permasih et al. (2014) rentang umur 15-64 tahun adalah rentang umur tenaga kerja usia produktif, dimana pada rentang usia tersebut barang atau jasa sudah dapat dihasilkan dalam proses produksi.

Pendidikan terakhir responden sebanyak 56\% lulusan SD, 20\% SMP, $20 \%$ SMA dan $4 \%$ lulusan akademi. Usia responden yang produktif tersebut, tidak diimbangi dengan tingkat pendidikan responden yang sebagian besar masih relatif rendah yaitu ditingkat SD, namun dengan begitu pengetahuan dan pengalaman responden tidak diragukan lagi dalam membudidayakan sayuran organik. Pengetahuan dan pengalaman responden diperoleh dari mengikuti berbagai kegiatan seperti penyuluhan, seminar, pameran produk pertanian dan pelatihan. Menurut Alam dan Hermawan (2017) tingkat pendidikan merupakan hal terpenting untuk dapat mempengaruhi pola pikir manusia dalam mengambil keputusan dan mengembangkan usahanya. Total responden 50 orang, sebanyak 38 responden memiliki luas lahan dengan rentang 0-1500 $\mathrm{m}^{2}$, 1501-3000 $\mathrm{m}^{2}$ sebanyak 5 responden, 3001-6000 $\mathrm{m}^{2}$ sebanyak 6 responden dan 1 responden dengan luas $>6000 \mathrm{~m}^{2}$. Luas lahan dari petani mitra sebagian besar tergolong sempit, namun tidak menjadi penghalang bagi petani untuk memenuhi permintaan sayuran dari PT Bloom Agro dan rumah tangga dikarenakan petani melakukan sistem tumpangsari. Menururt Chaerani (2019) penggolongan petani menurut kepemilikan luas lahan dan penguasaan atas tanah berpengaruh terhadap besarnya pendapatan, juga sangat ditentukan oleh kontribusi tanah sebagai dasar usahanya. Data karakteristik responden ditampilkan pada Tabel 1. 
Tabel 1. Karakteristik, Jumlah dan Persentase Responden

\begin{tabular}{llcc}
\hline No & Uraian & $\begin{array}{c}\text { Jumlah responden } \\
\text { (Orang) }\end{array}$ & Persentase (\%) \\
\hline $1 \quad$ Usia (tahun) & 2 & 4 \\
& $21-30$ & 14 & 28 \\
& $31-40$ & 13 & 26 \\
& $41-50$ & 12 & 24 \\
& $51-60$ & 9 & 18 \\
& $>60$ & & \\
2 & Pendidikan & 28 & 56 \\
& SD & 10 & 20 \\
& SMP & 10 & 20 \\
& SMA/SLTA & 2 & 4 \\
& Akademi & & 76 \\
& Luas Lahan (m $\left.{ }^{2}\right)$ & 38 & 10 \\
& 0 - 1500 & 5 & 12 \\
& 1501-3000 & 6 & 2 \\
& 3001-6000 & 1 & \\
& $\geq 6000$ & &
\end{tabular}

Sumber : Data Primer diolah (2020).

\section{Pola Kemitraan}

Kemitraan yang sudah terjalin oleh PT Bloom Agro dengan petani sayuran organik di Kecamatan Getasan yaitu inti plasma. Pihak perusahaan (inti) bertugas menyediakan manajemen, bimbingan teknis, sebagian sarana produksi, menampung dan memasarkan hasil produksi merupakan tugas dari pihak inti sedangkan pihak plasma bertugas untuk memenuhi isi perjanjian kerjasama yang telah disepakati. Petani (plasma) di Gapoktan Bangkit Merbabu menyediakan pengadaan barang berkualitas, lahan, tenaga kerja dan budidaya sayuran organik sampai pasca panen (pengemasan) sedangkan PT Bloom Agro membayar sertifikasi internasional sayuran organik, membeli dan membayar hasil produksi, memfasilitas dan mendanai bibit, teknologi, pengemasan dan pengiriman sayuran organik. Hal ini sesuai pendapat Hamid dan Munir (2011) yang menyatakan pola inti plasma dimana petani mitra memproduksi komoditas pertanian untuk perusahaan mitra sedangkan perusahaan mitra adalah pengusaha-pengusaha besar, pengusaha industri, pedagang besar atau eksportir yang menyediakan sarana produksi, biaya produksi dan bantuan lain yang dapat meningkatkan efisiensi dan produktivitas hasil pertanian.

PT Bloom Agro dan petani memiliki kesamaan visi dan misi yaitu mengembangkan budidaya organik untuk kesehatan dan kelestarian lingkungan, maka dari itu dalam kemitraan ini dilakukan kesepakatan antara perusahaan dan petani yang dituangkan dalam sebuah kontrak perjanjian 
kerjasama. Kontrak perjanjian mengandung aspek atau hal-hal berupa identitas dari pihak-pihak yang bermitra, hak dan kewajiban, syarat sayuran organik dan sanksi bagi yang melanggar. Menurut Herlina (2014) bahwa menjalin kemitraan memiliki syarat yaitu kedua belah pihak mempunyai kesamaan dalam mencapai tujuan, visi dan misi yang sejalan, saling membutuhkan satu sama lain dan mempunyai kesepakatan bersama.

\section{Analisis Tingkat Kepentingan dan Kinerja (IPA)}

Importance Performance Analysis (IPA) digunakan untuk menganalisis pelaksanaan kemitraan dengan mengukur tingkat kepentingan atau harapan dari petani dan kinerja atau kepuasan perusahaan dari atribut-atribut yang ditetapkan ke dalam skala prioritas.

Tabel 2. Hasil Perhitungan Rata-Rata Tingkat Kepentingan dan Kinerja

\begin{tabular}{|c|c|c|c|c|}
\hline No & Atribut & $\overline{\mathrm{X}}$ & $\bar{Y}$ & Tki \\
\hline 1 & $\begin{array}{l}\text { Kualitas benih yang diberikan oleh PT Bloom } \\
\text { Agro }\end{array}$ & 2,78 & 4,06 & 68,47 \\
\hline 2 & Tingkat pengetahuan teknisi lapangan & 4,14 & 4,62 & 89,61 \\
\hline 3 & $\begin{array}{l}\text { Respon teknisi lapangan terhadap keluhan } \\
\text { petani }\end{array}$ & 4,38 & 4,60 & 95,21 \\
\hline 4 & $\begin{array}{l}\text { Teknologi yang diberikan (bangsal } \\
\text { penyimpanan, alat packaging) }\end{array}$ & 4,78 & 4,52 & 105,75 \\
\hline 5 & $\begin{array}{l}\text { Terdapat SOP yang jelas mengenai penetapan } \\
\text { kualitas produk }\end{array}$ & 4,86 & 4,84 & 100,41 \\
\hline 6 & $\begin{array}{l}\text { Kesesuaian hasil panen yang diserap oleh } \\
\text { perusahaan }\end{array}$ & 3,84 & 4,22 & 90,99 \\
\hline 7 & Kesesuaian harga jual & 4,76 & 4,90 & 97,14 \\
\hline 8 & Kemudahan pengiriman produk & 4,86 & 4,76 & 102,10 \\
\hline 9 & Waktu pembayaran setelah penyetoran produk & 4,40 & 4,42 & 99,55 \\
\hline \multirow[t]{2}{*}{10} & Peningkatan pendapatan yang dirasakan petani & 4,98 & 4,80 & 103,75 \\
\hline & Rata-rata & 4,38 & 4,57 & 95,30 \\
\hline
\end{tabular}

Sumber : Data Primer diolah (2020).

Berdasarkan Tabel 2 diatas, terdapat 4 atribut yang mempunyai nilai persentase lebih dari $100 \%$ yaitu teknologi yang diberikan, standar operasional prosedur (SOP) yang jelas, kemudahan pengiriman produk dan penghasilan yang meningkat yang dirasakan oleh petani. Pada tingkat kesesuaian 80-100\%, terdapat 5 atribut yaitu tingkat pengetahuan teknisi lapangan, respon teknisi lapangan terhadap masalah petani, kesesuaian hasil panen yang diserap oleh perusahaan, kesesuaian harga jual dan tenggang masa pembayaran setelah penyetoran produk. Kualitas benih yang diberikan oleh PT Bloom Agro merupakan atribut yang mempunyai tingkat kesesuaian paling rendah yaitu 
$68,47 \%$. Hal tersebut dikarenakan benih yang diberikan oleh PT Bloom Agro sebagian besar ada yang tidak cocok dengan keadaan lingkungan lahan petani. Selama ini hampir semua petani membuat benih sendiri atau membeli di pasar untuk keperluan kebutuhan budidaya mereka guna memenuhi pesanan dari pihak mitra.

Keseluruhan atribut dapat disimpulkan bahwa petani merasakan kesesuaian antara kepentingan dan kinerja sudah sangat baik. Atribut-atribut tersebut telah bekerja sesuai harapan konsumen, namun perlu perbaikan lagi bagi atribut yang belum sesuai harapan. Atribut yang memiliki nilai jauh dari $100 \%$ yaitu atribut kualitas benih yang diberikan oleh PT Bloom Agro sebesar $68,47 \%$, maka dari itu harus diperbaiki lagi. Tingkat kesesuaian diperoleh skor rata-rata sebesar 95,30\%, dimana nilai tersebut menunjukan tingkat kesesuaian antara kepentingan petani dan kinerja perusahaan bisa dibilang sangat baik dan merasa sangat puas. Menurut Elias et al. (2015) pentingnya meningkatkan pelayanan dari atribut yang dianggap istimewa atau penting oleh petani tetapi hasil kinerja rendah dibanding meningkatkan atribut yang diyakini responden tidak atau kurang penting oleh petani tetapi kinerjanya tinggi.

Rata-rata nilai tingkat kinerja yaitu 4,38 dimana pada tingkat kinerja ini terdapat 7 atribut yang berada diatas rata-rata. Nilai rata - rata tingkat kepentingan yaitu 4,57 dimana 6 atribut berada diatas nilai rata-rata. Skala prioritas ditentukan oleh posisi kordinat, dimana posisi koordinat ditentukan oleh matriks X (kinerja) dan matriks Y (kepentingan).

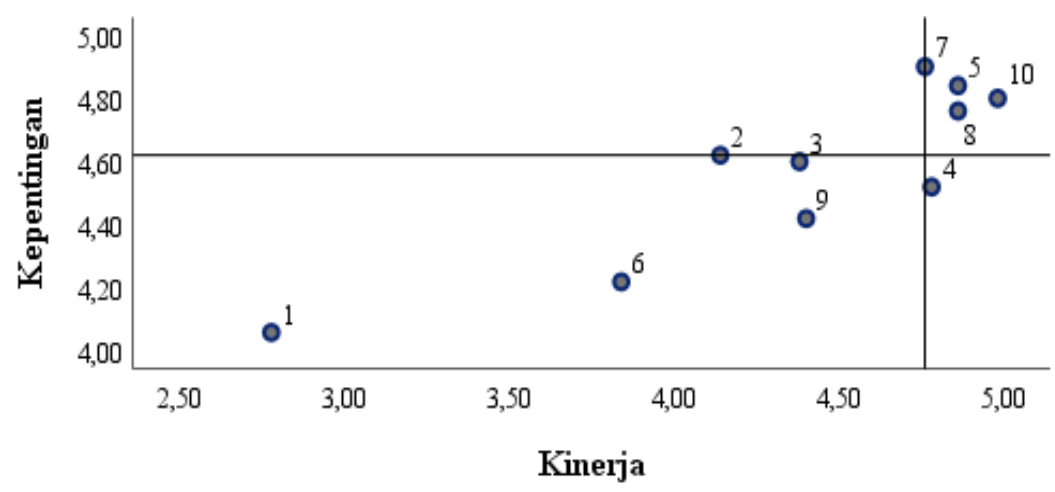

Gambar 2.

Hasil Diagram Kartesius Pengukuran IPA

Kuadran I (prioritas utama) terdapat 1 atribut yaitu atribut tingkat pengetahuan teknisi lapangan. Kuadran ini tingkat kepentingan sangat tinggi tetapi kinerja yang diberikan mitra belum sesuai harapan sehingga menjadi hal utama yang harus dilakukan perbaikan. 
Kuadran II (pertahankan prestasi) terdapat 4 atribut yaitu standar operasional prosedur (SOP) yang jelas, kesesuaian harga jual, transportasi pengiriman produk yang mudah dan penghasilan yang meningkat yang dirasakan petani. Pada kuadran ini perusahaan telah memberikan pelayanan atau jasa sesuai dengan ekspektasi petani sehingga petani merasa puas dan perusahaan hanya perlu mempertahankan kinerja atribut pada kuadran ini.

Kuadran III (prioritas rendah) yaitu kualitas benih yang diberikan oleh PT Bloom Agro, respon teknisi lapangan pada masalah petani, kesesuain hasil panen yang diserap oleh pihak mitra dan tenggang masa pembayaran setelah penyetoran produk. Atribut pada kuadran ini dirasa tidak terlalu istimewa oleh petani dan kinerja nya pun tidak terlalu tinggi atau rendah sehingga perusahaan tidak harus melakukan perbaikan di atribut-atribut pada kuadran ini.

Kuadran IV (berlebihan) terdapat atribut yaitu teknologi yang diberikan (bangsal penyimpanan dan alat packaging) dimana tingkat kepentingan dianggap rendah oleh petani tetapi memilki kinerja yang memuaskan. Bangsal penyimpanan tidak terlalu dibutuhkan oleh petani akan tetapi sangat membantu dalam proses pengiriman barang.

\section{Kepuasan Petani terhadap Pelayanan PT Bloom Agro berdasarkan CSI}

Tingkat kepuasan yang dirasakan petani terhadap program kemitraan dengan PT Bloom Agro diukur menggunakan Customer Satisfaction Index (CSI) dengan memperhatikan tingkat kepentingan dan kinerja atas atribut-atribut yang telah ditetapkan. Indeks kepuasan petani anggota Gapoktan Bangkit Merbabu terhadap pelayanan PT Bloom Agro ditampilkan pada Tabel 3.

Berdasarkan Tabel 3, hasil akhir perhitungan Customer Satisfaction Index atau (CSI) sebesar $88 \%$ atau 0,88 yang menunjukan petani bermitra dengan PT Bloom Agro secara menyeluruh merasa sangat puas terhadap kemitraaan yang dijalani. Menurut Simamora (2004) kriteria kepuasan dalam skala likert dibagi menjadi 5 yaitu $0 \%$ - 20\% (tidak puas), 20\% - 40\% (kurang puas), $41 \%-60 \%$ (cukup puas), $61 \%$ - 80\% (puas) dan $81 \%$ - 100\% (sangat puas). Rendahnya kendala (permasalahan) yang dihadapi petani dalam kemitraan yang terjalin menunjukan kemitraan berjalan dengan serasi. Menurut Saptana et al. (2016) permasalahan mendasar yang seringkali dihadapi oleh petani yaitu harga sarana produksi pertanian yang terus meningkat sedangkan harga produk pertanian sangat fluktuatif, dikarenakan lemah nya posisi tawar petani terhadap pelaku agribisnis lainnya. Kemitraan yang terjalin antara PT Bloom Agro dan petani sayuran organik sudah sangat baik, akan tetapi masih perlu dibutuhkan perbaikan lagi pada atribut yang diyakini penting oleh petani namun mempunyai nilai kinerja yang rendah. 
Tabel 3. Hasil Perhitungan Customer Satisfaction Index (CSI)

\begin{tabular}{ccrcc}
\hline $\begin{array}{c}\text { Atribut } \\
\text { Ke }\end{array}$ & $\begin{array}{c}\text { Rata-rata tingkat } \\
\text { kepentingan }(\mathrm{Y})\end{array}$ & $\begin{array}{c}\text { Wf } \\
(\%)\end{array}$ & $\begin{array}{c}\text { Rata-rata tingkat } \\
\text { kinerja }(\mathrm{X})\end{array}$ & $\begin{array}{c}\text { Ws } \\
(\%)\end{array}$ \\
\hline 1 & 4,06 & 8,88 & 2,78 & 0,25 \\
2 & 4,62 & 10,10 & 4,14 & 0,42 \\
3 & 4,60 & 10,06 & 4,38 & 0,44 \\
4 & 4,52 & 9,88 & 4,78 & 0,47 \\
5 & 4,84 & 10,58 & 4,86 & 0,51 \\
6 & 4,22 & 9,23 & 3,84 & 0,35 \\
7 & 4,90 & 10,71 & 4,76 & 0,51 \\
8 & 4,76 & 10,41 & 4,86 & 0,51 \\
9 & 4,42 & 9,66 & 4,40 & 0,43 \\
\multicolumn{7}{c}{10} & 4,80 & 10,49 & 4,98 & 0,52 \\
\hline Total & 45,74 & 100,00 & 43,78 & 4,41 \\
\hline \multicolumn{5}{c}{ Weighted total } \\
\multicolumn{7}{c}{ CSI }
\end{tabular}

Sumber : Data Primer diolah (2020).

\section{SIMPULAN DAN SARAN}

\section{Simpulan}

Pola kemitraan yang terjalin antara petani anggota Gapoktan Bangkit Merbabu dengan PT Bloom Agro yaitu inti plasma. PT Bloom Agro pada kemitraan ini memberikan bimbingan teknis mulai dari pra budidaya sampai pengiriman produk (pasca panen) dan menyerap hasil produksi petani mitra. Sedangkan petani mitra memenuhi sayuran organik sesuai standar mutu dan melakukan proses budidaya sesuai bimbingan teknis oleh perusahaan. Berdasarkan matriks IPA atribut yang menjadi point utama untuk dilakukan perbaikan yaitu tingkat pengetahuan teknisi lapangan. Nilai CSI sebesar $88 \%$ yang terletak antara $80 \%-100 \%$, artinya secara keseluruhan petani mitra sangat puas dalam mengikuti kerjasama usaha dengan pihak perusahaan yaitu PT Bloom Agro.

\section{Saran}

Berdasarkan hasil penelitian diatas, peneliti memberikan masukan sebagai berikut : 1) atribut tingkat pengetahuan teknisi lapangan menjadi prioritas utama untuk dilakukan perbaikan oleh perusahaan dengan cara meningkatkan pelayanan pada atribut. 2) Untuk peneliti selanjutnya diharapkan 
memperhatikan aspek-aspek yang masih perlu ditambahkan kedalam karakteristik penilaian dalam menilai kualitas pelayanan dari suatu kemitraan.

\section{DAFTAR PUSTAKA}

Alam, A. S dan H. Hermawan. 2017. Faktor-Faktor yang Mempengaruhi Hubungan Kemitraan antara Petani Budidaya Jamur Tiram dengan CV. Asa Agro Corporation. Jurnal Agroscience 7(1): 214 - 219.

Ariesusanty, L., S. Nuryanti dan Wangsa. 2010. Statistik Pertanian Organik Indonesia. Aliansi Organis Indonesia. Bogor.

Arifin, M. 2015. Analisis Tingkat Kepuasan Petani terhadap Kinerja Pelayanan Penyuluh Pertanian. Jurnal Agrica Ektensia 9(1): 40-49.

Badan Pusat Statistik (BPS) Kabupaten Semarang 2017. Kecamatan Getasan dalam Angka 2017. Badan Pusat Statistik Kabupaten Semarang, Semarang.

Bambang, S. B. 2013. Analisis tingkat kepuasan pelanggan dengan menggunakan metode Costumer Satisfaction Index dan Importance Performance Analysis. Jurnal REKAVASI 1(1) : 21-29.

Chaerani, D. S. 2019. Pengaruh Karakteristik sosial ekonomi petani terhadap pendapatan usahatani jagung manis anggota Gabungan Kelompok Tani Tunas Muda Kelurahan Kampung Juan Nan XX Kecamatan Lubuk Begalung Kota Padang. Jurnal Embrio 11(2) : 23 - 44.

Elias, A., M. Naomi., K. Yasunobu dan A. Ishida. 2015. Farmers' Satisfaction with Agricultural Extension Service and Its Influencing Factors: A Case Study in North West Ethiopia. Journal of Agricultural Science and Technology 18(1): 39-53.

Hamid, A dan Munir, H. 2011. Bertanam Cabai Hibrida untuk Industri. PT AgroMedia Pustaka. Jakarta.

Hidayatulloh, R., D. Koestiono dan B. Setiawan. 2015. Analisis Rantai Nilai (Value Chain) Usahatani Sayuran Organik (Studi Kasus pada Komunitas Organik Brenjok, Desa Penanggungan Kecamatan Trawas Kabupaten Mojokerto Jawa Timur). Jurnal Agrisep 15(1): 18-32.

Herlina, E. 2014. Pendidikan dan Pelatihan dalam Meningkatkan Model Kerjasama Usaha Menengah Kecil dan Mikro dengan Usaha Besar di Kecamatan Cikoneng Kabupaten Ciamis. Jurnal Manajemen Univeritas Galuh Ciamis, 1(1): 71 - 81.

Iswari, I. A. I. M., A. S. Wiranatha dan I. K. Satriawan. 2015. Analisis kepuasaan konsumen terhadap kualitas pelayanan dan jasa dengan menggunakan metode Importance Performance Analysis. Jurnal Rekayasa dan Manajemen Agroindustri 3(3) : 51- 60.

Mufarriqoh, Z. 2020. Statistika Pendidikan. CV Jakad Media Publishing. Surabaya. 
Musanif, J., S. B. Indrajanti, M. Putera, S. Wahyuni, Alfiansyah, H. M. Abidin, D. E. Waty, E. Saragih, R. Sinambela, F. Marcelinus dan J. Mariyanto. 2013. Pedoman Kemitraan Agribisnis. Kemitraan Pertanian, Jakarta.

Oglamando, G., Analianasari dan C. Fatih. 2017. Pola Kemitraan PT Sayuran Siap Saji dengan Mitra Beli Bawang Bombay di Jawa Barat. Karya Ilmiah Mahasiswa. Politeknik Negeri Lampung.

Permasih, J., S. Wijaya dan U. Kalsum. 2014. Proses Pengambilan Keputusan dan Faktor-Faktor yang Mempengaruhi Penggunaan Benih Jagung Hibrida oleh Petani di Kecamatan Adiluwihi Kabupaten Pringsewu. Jurnal IlmuIlmu Agribisnis 2(4): 1 - 10.

Raharjo, T. W. 2018. Pengembangan Ekonomi Masyarakat melalui Penguatan Kemitraan Usaha UMKM, Koperasi dan Korporasi. CV. Jakad Publishing. Surabaya.

Rangkuti, F. 2006. Measuring Custumer Satisfication : Gaining Custumer Relationship Strategy. PT Gramedia Pustaka Umum. Jakarta.

Sanusi, B. 2010. Sukses Bertanam Sayuran di Lahan Sempit. PT AgroMedia Pustaka. Jakarta.

Saptana., Sunarsih dan K. S. Indraningsih. 2016. Mewujudkan Keunggulan Komparatif Menjadi Keunggulan Kompetitif melalui Pengembangan Kemitraan Usaha Holtikultura. Forum Penelitian Agro Ekonomi 24(1): 61 $-76$.

Sari, F. 2018. Metode dalam Pengambilan Keputusan. DEEPUBLISH. Yogyakarta.

Simamora, B. 2004. Panduan Riset Perilaku Konsumen. Gramedia Pustaka Utama. Jakarta.

Statistik Pertanian Organik Indonesia (SPOI). 2019. Statistik Pertanian Organik Indonesia 2019. Aliansi Organis Indonesia. Bogor.

Sunria. 2020. Profil PT Bloom Agro. (www.sunria.com.) Diakes pada 3 Maret 2020. Yurlisa, K dan M. M. Susanti. (2018) Sertifikasi Produk Pertanian Organik. UB Press. Malang.

116 | Yola Arsela; Wiludjeng Roessali; Bambang Mulyatno Setiawan; Analisis... 